\title{
In vitro ruminal fermentation and methane production of different seaweed species
}

\author{
E. Molina-Alcaide , M.D. Carro, M.Y. Roleda , M.R. Weisbjerg , V. Lind , \\ M. Novoa-Garrido
}

A B S T R A C T

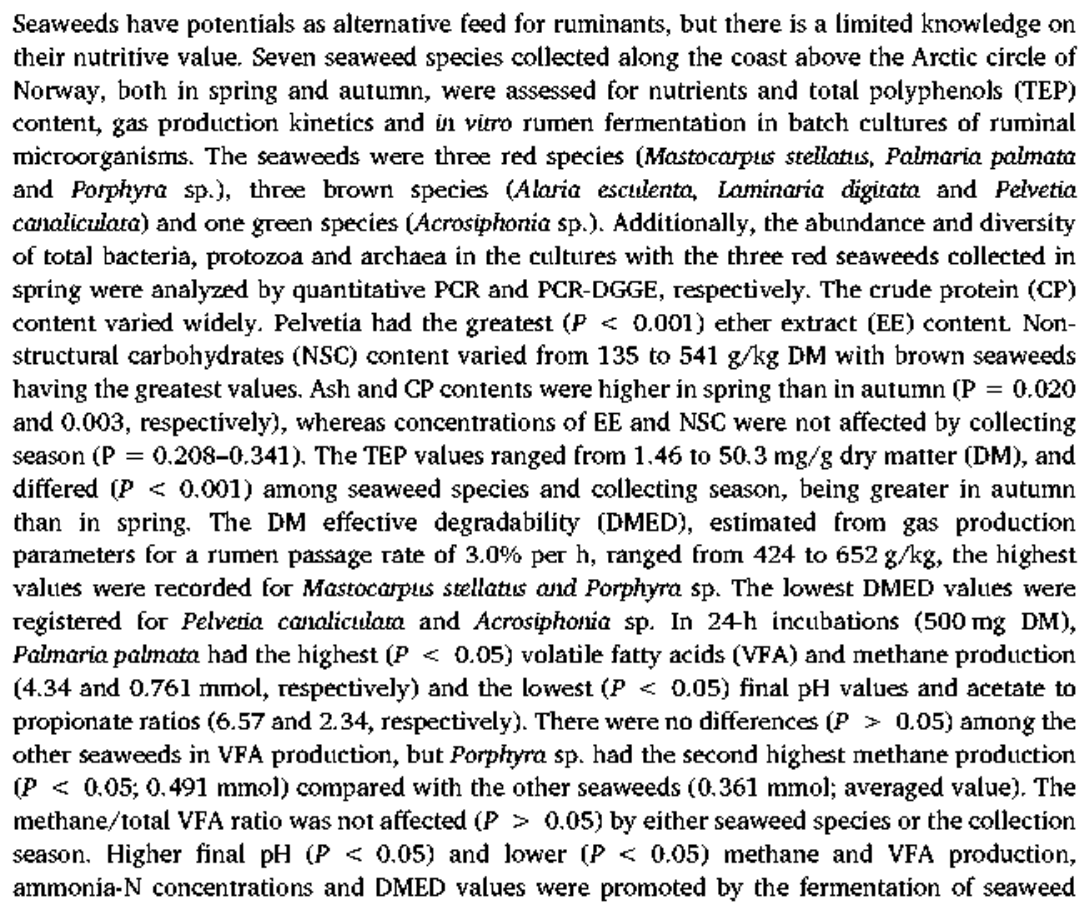

Abbreviations: AGPR. average gas production rate; CP. crude protein: DM. dry matter: DMED, DM effective degradability; DMD, $7272 \mathrm{DM}$ degradability after 72 h of incubation: EE. ether extract: NDF, neutral detergent fibre: NSC. non-structural carbohydrates: PCR. polymerase chain reaction; PCR-DGGE. PCR-denaturing gradient gel electrophoresis; $\mathrm{qPCR}$, quantitative PCR: TEP, total extractable polyphenols; $\mathrm{TDMD}_{72}$. True $\mathrm{DMD}_{72}$; VFA, volatile fatty acids 
collected in autumn compared with those from spring. Among the red seaweeds, there were no species-specific differences $(P>0.05)$ in the abundance or the diversity of total bacteria, protozoa and archaea. In the PCR-DGGE analysis, samples were separated by the incubation run for all microbial populations analyzed, but not by seaweed species. The results indicate that seaweed species differ markedly in their in vitro rumen degradation, and that samples collected in autumn had lower rumen degradability than those collected in spring.

\section{Introduction}

The world human population is estimated to reach 9.1 billion by 2050 , and the demand for meat and dairy products is rapidly increasing (Steinfeld and Wassenaar, 2007). In this context, the search for alternative feed sources for livestock, such as unconventional feedstuffs like seaweeds is a priority (Odegard and van der Voet, 2014). About 71\% area of earth's surface is covered by ocean, which holds about $96.5 \%$ of the planet's hydrosphere and a large fraction of body of water and its biota remains unexploited. Seaweeds are primary producers growing along coastal habitats under natural conditions of light and temperature. Cultivation of seaweed do not compete with agricultural land that can be utilized for the production of other valuable crops, do not require freshwater, and aquatic photosynthesis can help buffer the effect of increasing atmospheric $\mathrm{CO}_{2}$. Moreover, there is an increasing interest in using marine resources like seaweed in animal feeding as sources of protein to replace soya bean meal. Seaweeds are also interesting for their potential beneficial effects on animal and consumers health (Makkar et al., 2016). However, the use of seaweeds in feeding ruminants is limited due to the lack of information regarding species-specific nutritive value and variability, but also to the presence of substances which could be a challenge to the digestive system of terrestrial animals (Evans and Critchley, 2014; Makkar et al., 2016).

Seaweeds are macroscopic, multicellular marine algae and belong to three distinct evolutionary groups: green (phylum Chlorophyta), brown (phylum Ochrophyta), and red (phylum Rhodophyta). These three phyla differ considerably in their morphology (functional form), physiology, and biochemistry, and therefore also in chemical composition. Chemical composition of seaweed depends on various factors like species, harvesting season, habitat and light and water temperature, among others, and therefore a great variability is reported in the literature (Makkar et al., 2016). Some seaweeds are rich in protein (Tayyab et al., 2016) and others contain secondary compounds with variable biological activities which are almost unknown (Makkar et al., 2016). As livestock production relies heavily on the supply of high-quality protein feeds, with soybean being the most widely used plant protein source in Europe, protein rich seaweeds could potentially be an alternative to soybean protein (Tayyab et al., 2016).

Methane emission from enteric fermentation in animals is of concern worldwide due to its contribution to the accumulation of greenhouse gases in the atmosphere and an energy loss for the host animal (Hook et al., 2010). Recent studies suggest that red and brown seaweed species may have bioactive components with antimethanogenic properties (Belanche et al., 2016a; Kinley et al., 2016), although others (Belanche et al., 2016b) have failed to detect any influence on methane production. Differences in the seaweed species and inclusion rate can explain the variable results. Given the importance of this topic and the low number of studies in which the influence of seaweeds on methane emissions by ruminants has been assessed, further research is necessary.

The objective of the present study was therefore to provide information on nutrients and phenol composition and assess gas production kinetics, in vitro fermentation and methane emission of seven seaweed species (Alaria esculenta, Laminaria digitata, Pelvetia canaliculata, Mastocarpus stellatus, Palmaria palmata, Porphyra sp. and Acrosiphonia sp.) collected in northern Norway. These seaweed species were chosen primarily based on biomass availability, cultivation potential, biochemical composition (Holdt and Kraan, 2011), but also based on traditional use of seaweed for feeding animals, and observed feeding preference of free-range ruminants along coastal areas grazing on beach cast seaweeds (Bay-Larsen et al., 2016). Huge biomass of Alaria esculenta is seasonally available, while biomass of Palmaria palmata, Mastocarpus stellatus and Pelvetia canaliculata are available year-round with different seasonal peaks (Roleda M. Y. personal observation). Pelvetia canaliculata has been traditionally used to feed animals during lean season (i.e. winter months), and Palmaria palmata has been observed to be preferred by free-range sheep browsing through piles of beach-cast seaweeds (Bay-Larsen et al., 2016). The protein value of these seven species has been recently analysed in dairy cows by Tayyab et al. (2016), and the results showed that Acrosiphonia sp., Alaria esculenta, Laminaria digitata, Mastocarpus stellatus and Palmaria palmata can supply the rumen with high amounts of rumen degradable protein, while Porphyra sp. can be used as a source of digestible bypass protein. Seaweeds were collected in two seasons (spring and autumn) to assess seasonal variability of the seaweeds nutrients. In addition, the ruminal microbiota promoted by the fermentation of some of the seaweeds was analyzed.

\section{Materials and methods}

\subsection{Animals}

Two rumen-cannulated Segureña ewes $(50.9 \pm 2.91 \mathrm{~kg}$ body weight; 2 years old) were used as rumen contents' donors for the in vitro incubations. Animals were cared and handled by trained personnel in accordance with the Spanish guidelines for experimental animal protection (Royal Decree 53/2013 of February 1st on the protection of animals used for experimentation or other scientific purposes). All the experimental procedures were approved by the Animal Welfare Committee at the Estación Experimental del Zaidin (CSIC, Spain; Approval number: 24/05/2016/091). Animals were fed a standard diet composed of alfalfa hay and a commercial 
concentrate in a $1: 1$ ratio at $50 \mathrm{~g}$ per $\mathrm{Kg}$ body weight ${ }^{0.75}$, which corresponded to energy maintenance level (Aguilera et al., 1986). Chemical composition of the diets is shown in Table 1. Experimental diets were offered in two meals at 9:00 h and 18:00 h. Clean water and mineral supplement were always available. Concentrate (Pacsa Sanders, Seville, Spain) was provided as pellets and consisted ( $\mathrm{g} / \mathrm{kg}$ fresh matter) of wheat flour (350), sunflower meal (200), malt sprouts (80), canola meal (130), soybean hulls (200), calcium carbonate (10), rumen-inert fat (25) and sodium chloride (5). The composition ( $\mathrm{g} / \mathrm{kg}$ DM) of the diet was: organic matter (OM) 883, crude protein (CP) 185, neutral detergent fiber (aNDFom) 355, acid detergent fiber (aADFom) 224, ether extract (EE) 43 and $9.25 \mathrm{MJ} / \mathrm{kg}$ DM of ME.

\subsection{Seaweeds collection and preparation}

Seaweeds were collected by hand picking in spring (March) and autumn (October- November) 2014 in Bodø, Norway $\left(67^{\circ} 19^{\prime} 00^{\prime \prime} \mathrm{N}, 14^{\circ} 28^{\prime} 60^{\prime \prime} \mathrm{E}\right)$ during low tide. The collected seaweeds were three red species (Mastocarpus stellatus, Palmaria palmata and Porphyra sp.), three brown species (Alaria esculenta, Laminaria digitata and Pelvetia canaliculata) and one green species (Acrosiphonia sp.). The seaweed samples were first cleaned of sand and associated organisms in baths of seawater. Thereafter, the samples were briefly washed in water of decreasing salinity (30\%), and finally in freshwater to reduce surface salts. The excess water was drained manually and samples were frozen at $-20^{\circ} \mathrm{C}$. Finally, the samples were lyophilized and milled through a $1 \mathrm{~mm}$ screen with a cutter mill as described by Tayyab et al. (2016).

\subsection{In vitro incubations}

Samples of the lyophilized seaweeds were used as substrates for in vitro incubations using batch cultures of rumen microorganisms. Rumen contents were collected from the two sheep before the morning feeding, pooled and immediately taken to the laboratory into thermal flasks. Rumen contents were strained through four layers of cheesecloth and mixed with a buffer solution (Goering and Van Soest, 1970) in a 1:4 ratio (vol/vol) at $39{ }^{\circ} \mathrm{C}$ under continuous flushing with $\mathrm{CO}_{2}$. The time required from rumen content collection to inoculation of bottles was $<30 \mathrm{~min}$.

A total of six in vitro incubation runs were carried out, three for the samples collected in spring and three for the autumn-collected samples. Four bottles per sample and four bottles without substrate (blanks) were used in each run. Blanks were used to correct the gas production values for gas release from endogenous substrates. Samples $(0.500 \mathrm{~g})$ of seaweeds were carefully weighed into $120 \mathrm{ml}$

Table 1

Chemical composition (mg/g DM, excepting DM content) in different seaweed species collected during spring and autumn in northern Norway?

\begin{tabular}{|c|c|c|c|c|c|c|c|}
\hline Seaweed species & Season & $\mathrm{DM}$ & Ash & $\mathrm{CP}$ & $\mathrm{EE}$ & NSC & TEP \\
\hline \multicolumn{8}{|l|}{ Brown seaweeds } \\
\hline \multirow[t]{3}{*}{ Alaria esculenta } & Spring & 132 & 278 & 158 & 4.24 & 443 & 8.91 \\
\hline & Autumn & 237 & 139 & 127 & 4.92 & 639 & 50.3 \\
\hline & Average & 185 & $209^{\mathrm{ab}}$ & $143^{\mathrm{ab}}$ & $4.58^{c}$ & $541^{\mathrm{e}}$ & $29.6^{\mathrm{b}}$ \\
\hline \multirow[t]{3}{*}{ Laminaria digitata } & Spring & 128 & 351 & 161 & 3.35 & 322 & 1.46 \\
\hline & Autumn & 173 & 233 & 103 & 3.48 & 460 & 2.25 \\
\hline & Average & 151 & $292^{\mathrm{b}}$ & $132^{\mathrm{ab}}$ & $3.42^{b c}$ & $391^{\mathrm{c}}$ & $1.86^{\mathrm{a}}$ \\
\hline \multirow[t]{3}{*}{ Pelvetia canaliculata } & Spring & 229 & 219 & 105 & 28.4 & 355 & 18.8 \\
\hline & Autumn & 244 & 210 & 75.0 & 27.9 & 407 & 35.7 \\
\hline & Average & 237 & $215^{\mathrm{a}}$ & $90.0^{\mathrm{a}}$ & $28.2^{\mathrm{e}}$ & $381^{\text {be }}$ & $27.2^{\mathrm{b}}$ \\
\hline \multicolumn{8}{|l|}{ Red seaweeds } \\
\hline \multirow[t]{3}{*}{ Mastocarpus stellatus } & Spring & 283 & 217 & 178 & 0.564 & 456 & 3.44 \\
\hline & Autumn & 254 & 208 & 178 & 0.583 & 262 & 4.21 \\
\hline & Average & 269 & $213^{\text {at }}$ & $178^{\mathrm{bc}}$ & $0.574^{a}$ & $359^{\mathrm{bc}}$ & $3.82^{\mathrm{a}}$ \\
\hline \multirow[t]{3}{*}{ Palmaria palmata } & Spring & 160 & 165 & 257 & 3.33 & 154 & 3.97 \\
\hline & Autumn & 200 & 108 & 188 & 1.63 & 201 & 2.59 \\
\hline & Average & 180 & $137^{\mathrm{a}}$ & $223^{c}$ & $2.48^{\mathrm{b}}$ & $178^{\mathrm{ab}}$ & $3.28^{\mathrm{a}}$ \\
\hline \multirow[t]{3}{*}{ Porphyra sp. } & Spring & 148 & 149 & 372 & 0.458 & 108 & 3.64 \\
\hline & Autumn & 105 & 107 & 321 & 0.823 & 163 & 4.76 \\
\hline & Average & 127 & $128^{\mathrm{A}}$ & $347^{\mathrm{d}}$ & $0.641^{\mathrm{a}}$ & $135^{a}$ & $4.20^{\mathrm{a}}$ \\
\hline \multicolumn{8}{|l|}{ Green seaweeds } \\
\hline \multirow[t]{3}{*}{ Acrosiphonia sp. } & Spring & 226 & 171 & 333 & 7.63 & 82.4 & 3.88 \\
\hline & Autumn & 194 & 127 & 286 & 6.09 & 193 & 5.17 \\
\hline & Average & 210 & $149^{\mathrm{ab}}$ & $310^{d}$ & $6.86^{d}$ & $138^{\mathrm{a}}$ & $4.52^{\mathrm{a}}$ \\
\hline \multicolumn{8}{|l|}{$P$ value } \\
\hline Species & & 0.093 & 0.003 & $<0.001$ & $<0.001$ & 0.021 & $<0.001$ \\
\hline Season & & 0.171 & 0.020 & 0.003 & 0.341 & 0.261 & $<0.001$ \\
\hline SEM & & 39.9 & 35.8 & 16.1 & 0.658 & 87.5 & 0.368 \\
\hline
\end{tabular}

e,b,c,d,e Average values for each seaweed not sharing the same superscript differ $(P<0.05)$

${ }^{1}$ Data on DM, ash, CP and aNDFom content were reported previously by Tayyab et al. (2016). DM: dry matter ( $\mathrm{g} / \mathrm{kg}$ ); CP: crude protein; aNDFom: ash free neutral detergent fiber; EE: ether extract; NSC: non-structural carbohydrates calculated as 1000-(ash + CP + aNDFom + EE); TEP: total extractable polyphenols. 
bottles, and $60 \mathrm{ml}$ of the buffered rumen fluid were anaerobically added into each bottle. Bottles were sealed with butyl rubber stoppers and aluminum caps and incubated at $39^{\circ} \mathrm{C}$ in a water bath. In two of the four bottles for each seaweed sample and two blanks, pressure and gas volume were measured at 2, 4, 6, 8, 12, 24, 48 and $72 \mathrm{~h}$ of incubation using a Wide Range Pressure Meter (Sper Scientific LTD, Scottsdale, AZ, USA) and a glass-calibrated syringe (Ruthe ${ }^{\star}$, Normax, Marinha Grande, Portugal), respectively. After $72 \mathrm{~h}$, the content of bottles was freeze-dried and the DM residue determined to calculate the $\mathrm{DM}$ degradability $\left(\mathrm{DMD} \mathrm{D}_{72}\right)$. Finally, the residue was analyzed for aNDF $O$ m to calculate true DM degradability (TDMD 72 ; Van Soest et al., 1966).

In the remaining two bottles for each sample, the gas produced after $24 \mathrm{~h}$ of incubation was measured as described above and a gas sample (about $5 \mathrm{ml}$ ) was stored in an evacuated tube (Terumo Europe N.V., Leuven, Belgium) for analysis of methane. Bottles were then uncapped, the $\mathrm{pH}$ was measured immediately (Crison Basic $20 \mathrm{pH}$-meter, Crisson Instruments, Barcelona. Spain), the fermentation was stopped by placing the bottles in iced-water, and the following samples were taken: $2 \mathrm{ml}$ was added to $2 \mathrm{ml}$ of deproteinising solution ( $20 \mathrm{~g}$ of metaphosphoric acid and $0.6 \mathrm{~g}$ of crotonic acid per litre) for VFA determination, $1 \mathrm{ml}$ was mixed with $1 \mathrm{ml} 0.5 \mathrm{M} \mathrm{HCl}$ for $\mathrm{NH}_{3}-\mathrm{N}$ analysis, and $5 \mathrm{ml}$ were transferred to sterile containers and frozen at $-80^{\circ} \mathrm{C}$ for further analyses.

\subsection{DNA isolation and quantitative PCR and PCR-DGGE analyses}

The DNA isolation and molecular analyses were performed on the content of the cultures in which samples of the red seaweeds (Mastocarpus stellatus, Palmaria palmata and Porphyra sp.) collected in spring were fermented. These seaweeds were selected for these analyses due to the relatively high CP content (178-372 g/ kg; Table 1) and high DMED values (Table 2), as discussed later. Samples of cultures' contents collected at the end of the $24 \mathrm{~h}$ fermentations in sterile containers were freeze-dried, pooled by seaweed (within each run), and $50 \mathrm{mg}$ were homogenized with steel beads $(2.3 \mathrm{~mm}$ ) in a Mini-Bead-beater 8 (BioSpec Inc, Bartlesville, OK; USA) before DNA extraction following the repeated bead beating plus column (RBB $+\mathrm{C}$ ) procedure described by Yu and Morrison (2004). The OneStep ${ }^{\text {rx }}$ PCR Inhibitor Removal Kit (Zymo Research, USA) was used to remove PCR inhibitors and the QIAmp ${ }^{\circ}$ DNA Stool Mini

Table 2

In vitro gas production kinetics, dry matter effective degradability (DMED) and true DM digestibility after $72 \mathrm{~h}$ of incubation (TDMD 72 ) of different seaweed species collected during spring and autumn in northern Norway.

\begin{tabular}{|c|c|c|c|c|c|c|c|}
\hline \multirow[b]{2}{*}{ Seaweeds species } & \multirow[b]{2}{*}{ Season } & \multicolumn{4}{|c|}{ Parameters of gas production kinetics } & \multirow[b]{2}{*}{$\begin{array}{l}\text { DMED } \\
(\mathrm{g} / \mathrm{kg})^{2}\end{array}$} & \multirow[b]{2}{*}{$\begin{array}{l}\mathrm{TDMD}_{72} \\
(\mathrm{~g} / \mathrm{kg})^{3}\end{array}$} \\
\hline & & $A(m l)$ & $c($ per $h)$ & $\operatorname{Lag}(\mathrm{h})$ & $\begin{array}{l}\text { AGPR } \\
\text { (mL/g DM) }\end{array}$ & & \\
\hline \multicolumn{8}{|l|}{ Brown seaweeds } \\
\hline \multirow[t]{3}{*}{ Alaria esculenta } & Spring & 64.8 & 0.047 & 0.00 & 2.32 & 501 & 814 \\
\hline & Autumn & 51.1 & 0.063 & 0.00 & 2.13 & 449 & 664 \\
\hline & Average & $58.0^{\mathrm{d}}$ & $0.055^{a}$ & $0.00^{\mathrm{a}}$ & $2.23^{\mathrm{c}}$ & $475^{a b}$ & $739^{b}$ \\
\hline \multirow[t]{3}{*}{ Laminaria digitata } & Spring & 93.7 & 0.035 & 0.00 & 2.38 & 483 & 895 \\
\hline & Autumn & 79.8 & 0.057 & 0.00 & 3.27 & 557 & 852 \\
\hline & Average & $86.8^{\mathrm{e}}$ & $0.046^{\mathrm{a}}$ & $0.00^{\mathrm{a}}$ & $2.83^{c}$ & $520^{\mathrm{b}}$ & $874^{\text {de }}$ \\
\hline \multirow[t]{3}{*}{ Pelvetia canaliculata } & Spring & 11.9 & 0.096 & 0.00 & 0.73 & 463 & 602 \\
\hline & Autumn & 8.58 & 0.123 & 0.61 & 0.69 & 424 & 559 \\
\hline & Average & $10.2^{a}$ & $0.111^{\mathrm{cd}}$ & $0.31^{\mathrm{a}}$ & $0.71^{\mathrm{a}}$ & $444^{2}$ & $581^{\mathrm{a}}$ \\
\hline \multicolumn{8}{|l|}{ Red seaweeds } \\
\hline \multirow[t]{3}{*}{ Mastocarpus stellatus } & Spring & 18.8 & 0.113 & 0.00 & 1.50 & 652 & 829 \\
\hline & Autumn & 15.9 & 0.115 & 0.00 & 1.40 & 639 & 858 \\
\hline & Average & $17.4^{\mathrm{a}}$ & $0.119^{d}$ & $0.00^{\mathrm{a}}$ & $1.45^{b}$ & $646^{\mathrm{d}}$ & $844^{d}$ \\
\hline \multirow[t]{3}{*}{ Palmaria palmata } & Spring & 118 & 0.060 & 1.48 & 4.55 & 525 & 860 \\
\hline & Autumn & 127 & 0.096 & 0.89 & 7.85 & 640 & 914 \\
\hline & Average & $123^{f}$ & $0.078^{b}$ & $1.19^{b}$ & $6.20^{d}$ & $583^{\mathrm{c}}$ & $887^{\circ}$ \\
\hline \multirow[t]{3}{*}{ Porphyra sp. } & Spring & 31.9 & 0.093 & 0.09 & 2.05 & 588 & 787 \\
\hline & Autumn & 41.8 & 0.097 & 0.00 & 3.26 & 629 & 821 \\
\hline & Average & $36.9^{\mathrm{b}}$ & $0.095^{b e}$ & $0.05^{\mathrm{a}}$ & $2.66^{\mathrm{c}}$ & $609^{d}$ & $804^{c}$ \\
\hline \multicolumn{8}{|l|}{ Green seaweeds } \\
\hline \multirow[t]{3}{*}{ Acrosiphonia sp. } & Spring & 45.2 & 0.059 & 0.00 & 1.75 & 443 & 627 \\
\hline & Autumn & 55.0 & 0.096 & 0.00 & 3.79 & 463 & 610 \\
\hline & Average & $50.1^{c}$ & $0.077^{b}$ & $0.00^{\mathrm{a}}$ & $2.80^{\mathrm{c}}$ & $453^{\mathrm{a}}$ & $619^{\mathrm{a}}$ \\
\hline \multicolumn{8}{|l|}{$P$ value } \\
\hline Species & & $<0.001$ & $<0.001$ & $<0.001$ & $<0.001$ & $<0.001$ & $<0.001$ \\
\hline Season & & 0.301 & $<0.001$ & 0.928 & $<0.001$ & $<0.001$ & 0.091 \\
\hline Species $\mathrm{x}$ Season & & 0.002 & 0.337 & 0.353 & $<0.001$ & $<0.001$ & $<0.001$ \\
\hline SEM & & 1.01 & 0.0029 & 0.066 & 0.093 & 7.1 & 5.0 \\
\hline
\end{tabular}

\footnotetext{
${ }^{a-f}$ : Within each column, average values for each seaweed not sharing the same superscript differ $(\mathrm{P}<0.05)$.

${ }^{1} \mathrm{~A}$ : asymptotic gas production; $c$ : fractional rate of gas production; Lag: initial time delay in the onset of gas production; AGPR: average gas production rate.

${ }^{2}$ DMED: Dry matter effective degradability for a rumen particulate outflow of $0.03 / \mathrm{h}$.

${ }^{3}$ Calculated as described by Van Soest et al. (1966).
} 
Kit columns (QIAgen, Valencia, CA) were used to purify the DNA. The yield and purity of the extracted DNA were assessed using a NanoDrop ND-1000 Spectrophotometer (NanoDrop Technologies, Wilmington, DE).

The DNA samples were used as templates for quantifying the copy numbers of $16 \mathrm{~S}$ rRNA (for bacteria), the methyl coenzyme M reductase A (mcrA) gene (for methanogenic archaea), and 18S rRNA (for protozoa) through quantitative PCR (qPCR) as described by Martínez-Fernández et al. (2015), with some modifications in the cycling conditions. Primers used for total bacteria have been described by Maeda et al. (2003) and those for protozoa and methanogenic archaea have been described by Sylvester et al. (2004) and Denman et al. (2007), respectively. Cycling conditions were $95^{\circ} \mathrm{C}$ for $5 \mathrm{~min}$, followed by 40 cycles at $95{ }^{\circ} \mathrm{C}$ for $15 \mathrm{~s}$, $60{ }^{\circ} \mathrm{C}$ for $30 \mathrm{~s}, 72{ }^{\circ} \mathrm{C}$ for $55 \mathrm{~s}$ and $75^{\circ} \mathrm{C}$ for $6 \mathrm{~s}$, and final extension at $95^{\circ} \mathrm{C}$ for $1 \mathrm{~min}$ and $75{ }^{\circ} \mathrm{C}$ for $1 \mathrm{~min}$. Melting curves were obtained by 81 cycles at $55^{\circ} \mathrm{C}$ for $10 \mathrm{~s}$. The qPCR analyses were performed in triplicate with an iQ5 multicolor qPCR Detection System (BioRad Laboratories, Hercules, CA, USA). The absolute amount of DNA for each microbial group, expressed as the number of DNA copies per gram of fresh matter, was determined with standards. The standards are described in detail in Martínez-Fernández et al. (2015). The absolute amounts of each group of microorganisms were expressed as the corresponding gene copies per $\mathrm{g}$ fresh matter sample, and to attain normality, data on gene copies per $\mathrm{g}$ fresh matter were transformed using $\log _{10}$ before statistical analysis.

For PCR-DGGE analysis of total bacteria, the V3 region of the 16S rRNA gene was amplified as described by Abecia et al. (2014) using the bacterial primers described by Muyzer et al. (1993). For PCR-DGGE analysis of archaeal community, the mcrA gene was amplified as described by Abecia et al. (2012) using the primers described by Cheng et al. (2009). For the protozoa community, the $18 \mathrm{~S}$ rRNA was amplified using the primers described by Regensbogenova et al. (2004) and following the procedure of De la Fuente et al. (2009). The DGGE analyses were performed using the BDH system from VWR International Ltd (UK). The DNA was visualised by silver staining with a Bio-Rad Silver stain kit and scanned DGGE images were analysed with the Quantity One Software (BioRad, Madrid, Spain) by scoring for the presence or absence of bands at different positions in each line. The Shannon's diversity index was used to evaluate the diversity of bacterial communities, and dendrograms were constructed using the percent similarity and unweighted pair-group method using arithmetic averages (UPGMA) options in the MVSP v3.12d software (Kovach Computing Service, Anglesey, Wales, UK).

\subsection{Chemical analyses}

Procedures for analysis of DM, ash, CP and NDFom in seaweed species are detailed in Tayyab et al. (2016). Briefly, DM concentration was estimated as freeze dry matter and ash was determined as residue after combustion at $525{ }^{\circ} \mathrm{C}$. The $\mathrm{CP}$ values were calculated as $\mathrm{N} \times 6.25$ after $\mathrm{N}$ analysis by the Kjeldahl method. The aNDFom content was measured using FibertecTMM6 system (Foss Analytical, Hillerød, Denmark) using heat stable amylase and sodium sulphite according to the procedure described by Mertens (2002) and expressed exclusive of residual ash. Total extractable polyphenols (TEP) content was analyzed according to JulkunenTiito (1985). Ether extract content was determined by ether extraction (AOAC, 2005). The amount of non-structural carbohydrates (NSC) was calculated as [1000 - (ash + CP + aNDFom + EE)], all expressed as $\mathrm{g} / \mathrm{kg} \mathrm{DM}$.

Individual VFA concentrations were analyzed by gas chromatography described by Isac et al. (1994), using an Autosystem PerkinElmer Cor., Norwolk, CT equipped with a crosslinked $100 \%$ polyethylene glycol column (TRB-FFAP, $30 \mathrm{~m} \times 0.53 \mathrm{~mm}$ i.d. $\times 1 \mu \mathrm{m}$ film thickness, Teknokroma, Madrid, Spain). Methane concentration was determined by gas chromatography using a HP Hewlett 5890 Packard Series II gas chromatograph (Waldbronn, Germany) equipped with a flame ionization detector (FID) and an HPINNOWAX cross linked polyethylene glycol column ( $25 \mathrm{~m} \times 0.2 \mathrm{~mm} \times 0.2 \mu \mathrm{m}$; Teknokroma, Madrid, Spain). The carrier gas was $\mathrm{N}_{2}$ and peaks were identified by comparison with a standard of known composition. A sample of $0.5 \mathrm{ml}$ of gas was injected using a $1 \mathrm{ml}$ Sample-Lock" syringe (Hamilton, Reno, NV, USA). The amount of methane produced in each culture was calculated by multiplying the total gas produced by the concentration of methane obtained. Ammonia concentration was determined by following the methodology of Weatherburn (1967).

\subsection{Calculations and statistical analysis}

Gas production data were fitted to the exponential model: gas $=\mathrm{A}\left(1-\mathrm{e}^{(-c(\mathrm{t}-\operatorname{lag})}\right)$, where $\mathrm{A}$ is the asymptotic gas production, $c$ is the fractional rate of gas production, lag is the initial delay in the onset of gas production, and t is the time of gas measurement. The parameters A, $c$ and lag were estimated by an iterative least squares procedure using the NLIN procedures of SAS (version 9.4; SAS Inst. Inc., Cary, NC, USA). The average gas production rate (AGPR; $\mathrm{mL}$ gas/h) is defined as the average gas production rate between the start of the incubation and $\mathrm{T}_{1 / 2}$, and was calculated as AGPR $=\mathrm{A} c /[2(\ln 2+c \operatorname{lag})]$. Finally, the DM effective degradability (DMED) was estimated assuming a rumen particulate outflow $\left(\mathrm{K}_{\mathrm{p}}\right)$ of 0.03 per $\mathrm{h}$ according to the equation: $\mathrm{DMED}=\left[\left(\mathrm{DMD} \mathrm{D}_{72} c\right) /(c\right.$ $\left.\left.+K_{p}\right)\right] \mathrm{e}^{(- \text {clag })}$. The amount of VFA in each batch culture after $24 \mathrm{~h}$ of incubation was corrected for the amount of VFA in the rumen fluid used as inoculum.

Within each incubation run, the values measured in the two bottles incubated for 24 or $72 \mathrm{~h}$ for each seaweed sample were averaged before statistical analysis (three replicates per sample). All data were analyzed as a mixed model using the PROC MIXED of SAS (version 9.4; SAS Inst. Inc., Cary, NC, USA) with seaweeds species, season and seaweeds species x season interaction as fixed effects and incubation run as random effect. When a significant effect of seaweeds species $(P \leq 0.05)$ was detected, differences among means were tested using the Tukey's multiple comparison test. Relationships between chemical composition and DM degradability and gas production parameters were investigated by linear regression using the PROC CORR of SAS (SAS Inst. Inc., Cary, NC, USA). 


\section{Results}

\subsection{Chemical composition}

Chemical composition of seaweeds was affected by both seaweed species and collecting season, with the exception of DM content (Table 1). In general, brown seaweeds had greater ash concentrations compared with red and green species. The CP content varied widely, with Porphyra and Acrosiphonia having the greatest $(P<0.05)$ contents and all brown species showing values lower than $145 \mathrm{~g} / \mathrm{kg}$ DM. Alaria, Laminaria and Mastocarpus had aNDFom concentrations lower than $260 \mathrm{~g} / \mathrm{kg}$ DM, whereas Palmaria had values above $450 \mathrm{~g} / \mathrm{kg}$ DM. Pelvetia had the greatest $(P<0.001)$ EE content and Porphyra sp. and Palmaria had the lowest contents. The NSC content vatied from 135 to $541 \mathrm{~g} / \mathrm{kg}$ DM (values averaged across seasons), with brown seaweeds having the greatest values. Ash and $C P$ contents were higher in spring than in autumn ( $P=0.020$ and 0.003 , respectively), whereas concentrations of aNDFom, EE and NSC were not affected by collecting season ( $P=0.208-0.341)$. Total extractable polyphenols (TEP) content ranged from 1.46 ( $L$. digitata, spring sample) to 50.3 (A. esculenta, autumn sample) $\mathrm{mg} / \mathrm{g} \mathrm{DM}$, and differed among seaweed species ( $P<0.001$ ) and collecting season $(P<0.001)$. Alaria esculenta and Pelvetia canaliculata had higher $(P<0.05)$ TEP contents than the rest of the seaweeds in both seasons. Contents of TEP in the samples collected in autumn were higher $(P<0.001)$ than those in collected in spring.

\subsection{Gas production kinetics}

The parameters of gas production kinetics of the seaweeds are presented in Table 2. Seaweed species $\times$ season interactions were detected for A $(P=0.002)$, AGPR $(P<0.001)$, DMED $(P<0.001)$, and TDMD $72(P<0.001)$. There were differences $(P<0.001)$ among seaweeds species in all the gas production parameters measured, as well as in the DMED and TDMD 72 . In contrast, season did not affect $(P>0.05)$ the values of A and lag, but autumn-samples had greater values $(P<0.001)$ of $c(0.092$ vs. 0.072 per h), AGPR (3.20 vs. $2.18 \mathrm{ml} / \mathrm{h})$ and DMED (543 vs. $522 \mathrm{~g} / \mathrm{kg})$ compared with spring-samples. The highest $(P<0.05)$ values

Table 3

Total volatile fatty acids (VFA). molar proportions of individual VFA and acetate:propionate ratios (Ac/ $\mathrm{Pr}$ ) after 24h in vitro incubation of seaweeds of different seaweed species collected during spring and autumn in northern Norway in batch cultures of ruminal microorganisms.

\begin{tabular}{|c|c|c|c|c|c|c|c|c|c|}
\hline \multirow[b]{2}{*}{ Seaweed species } & \multirow[b]{2}{*}{ Season } & \multirow[b]{2}{*}{$\begin{array}{l}\text { VFA } \\
\text { (mmol) }\end{array}$} & \multicolumn{6}{|c|}{ Molar proportions $(\mathrm{mol} / 100 \mathrm{~mol})^{1}$} & \multirow[b]{2}{*}{$\mathrm{Ac} / \mathrm{Pr}(\mathrm{mol} / \mathrm{mol})$} \\
\hline & & & AC & $\mathrm{Pr}$ & But & Isobut & lsoval & Val & \\
\hline \multicolumn{10}{|l|}{ Brown seaweeds } \\
\hline \multirow[t]{3}{*}{ Alaria esculenta } & Spring & 3.48 & 60.4 & 15.9 & 17.1 & 1.50 & 3.03 & 2.10 & 3.84 \\
\hline & Autumn & 1.35 & 51.4 & 21.7 & 19.0 & 1.16 & 1.42 & 5.55 & 2.37 \\
\hline & Average & $2.42^{\mathrm{a}}$ & 55.9 & $18.8^{b}$ & $18.1^{\mathrm{b}}$ & $1.33^{\mathrm{ab}}$ & $2.23^{\mathrm{a}}$ & $3.83^{4}$ & $3.08^{b}$ \\
\hline \multirow[t]{3}{*}{ Laminaria digitata } & Spring & 3.14 & 64.6 & 13.4 & 14.1 & 1.76 & 4.11 & 2.00 & 4.81 \\
\hline & Autumn & 1.78 & 55.2 & 21.2 & 17.1 & 1.54 & 2.46 & 2.15 & 2.62 \\
\hline & Average & $2.46^{\mathrm{A}}$ & 59.9 & $17.3^{b}$ & $15.6^{\mathrm{ab}}$ & $1.65^{b c}$ & $3.29^{\mathrm{bc}}$ & $2.05^{\mathrm{a}}$ & $3.71^{\text {bc }}$ \\
\hline \multirow[t]{3}{*}{ Pelvetia canaliculata } & Spring & 2.97 & 57.7 & 13.5 & 21.4 & 1.62 & 3.67 & 2.15 & 4.29 \\
\hline & Autumn & 0.73 & 59.6 & 14.1 & 16.2 & 1.51 & 1.80 & 6.94 & 4.27 \\
\hline & Average & $1.85^{\mathrm{a}}$ & $\mathbf{5 8 . 7}$ & $13.8^{\mathrm{a}}$ & $18.8^{b}$ & $1.57^{\mathrm{Ab}}$ & $2.74^{\mathrm{ab}}$ & $4.55^{e}$ & $4.25^{d}$ \\
\hline \multicolumn{10}{|l|}{ Red seaweeds } \\
\hline \multirow[t]{3}{*}{ Mastocarpus stellans } & Spring & 2.79 & 55.2 & 14.4 & 21.1 & 2.10 & 4.68 & 2.51 & 3.85 \\
\hline & Autumn & 0.88 & 62.5 & 15.2 & 11.9 & 2.47 & 4.41 & 4.70 & 4.17 \\
\hline & Average & $1.84^{\mathrm{n}}$ & 58.9 & $14.8^{\mathrm{n}}$ & $16.5^{\mathrm{ab}}$ & $2.29^{\mathrm{cd}}$ & $4.55^{c}$ & $3.61^{\mathrm{cd}}$ & $3.97^{\mathrm{cd}}$ \\
\hline \multirow[t]{3}{*}{ Palmaria palmata } & Spring & 5.02 & 55.4 & 23.0 & 15.1 & 1.31 & 2.57 & 2.65 & 2.41 \\
\hline & Autumn & 3.66 & 59.3 & 26.0 & 9.22 & 1.13 & 1.62 & 2.81 & 2.28 \\
\hline & Average & $4.34^{b}$ & 57.4 & $24.5^{t}$ & $12.2^{\mathrm{a}}$ & $1.22^{\mathrm{a}}$ & $2.10^{\mathrm{a}}$ & $2.73^{a b}$ & $2.34^{a}$ \\
\hline \multirow[t]{3}{*}{ Porphyra sp. } & Spring & 3.07 & 58.3 & 16.8 & 15.9 & 2.26 & 4.63 & 2.72 & 3.47 \\
\hline & Autumn & 1.80 & 59.8 & 18.1 & 13.7 & 2.56 & 3.77 & 2.82 & 3.52 \\
\hline & Average & $2.43^{\mathrm{n}}$ & 59.1 & $17.5^{b}$ & $14.8^{\mathrm{n}}$ & $2.41^{d}$ & $4.20^{\mathrm{c}}$ & $2.77^{b}$ & $3.39^{b}$ \\
\hline \multicolumn{10}{|l|}{ Green seaweeds } \\
\hline \multirow[t]{3}{*}{ Acrosiphonia sp. } & Spring & 3.63 & 58.8 & 14.1 & 15.9 & 1.99 & 4.36 & 2.84 & 4.40 \\
\hline & Autumn & 1.83 & 62.1 & 20.1 & 11.5 & 2.06 & 3.19 & 3.04 & 3.00 \\
\hline & Average & $2.73^{\mathrm{A}}$ & 60.5 & $17.1^{\mathrm{ab}}$ & $13.2^{\mathrm{A}}$ & $2.03^{t}$ & $3.78^{\text {be }}$ & $2.94^{b c}$ & $3.70^{b c}$ \\
\hline \multicolumn{10}{|l|}{$P$ value } \\
\hline Species & & 0.033 & 0.408 & $<0.001$ & 0.042 & $<0.001$ & $<0.001$ & $<0.001$ & $<0.001$ \\
\hline Season & & $<0.001$ & 0.407 & $<0.001$ & 0.001 & 0.831 & $<0.001$ & $<0.001$ & $<0.001$ \\
\hline Species $x$ Season & & 0.981 & 0.002 & $<0.001$ & 0.043 & 0.268 & 0.798 & $<0.001$ & $<0.001$ \\
\hline SEM & & 0.213 & 0.718 & 0.474 & 0.713 & 0.0546 & 0.180 & 0.105 & 0.072 \\
\hline
\end{tabular}

\footnotetext{
n,b: Within each column, average values for each seaweed not sharing the same superscript differ $(P<0.05)$.

1 Ac: acetate; Pr: propionate; Bt: butyrate; Isobut isoburyrate; lsovalerate: isovalerate; Val: valerate.
} 
for A and AGPR were obsetved for Palmaria palmata (123 ml $6.20 \mathrm{ml} / \mathrm{h}$, respectively; mean actoss seasons) and the lowest ones for Pelvetia canaliculata $(10.2 \mathrm{ml}$ and $0.71 \mathrm{ml} / \mathrm{h}$, respectively). Mastocarpus stellatus had the highest $(P<0.05)$ gas production rate $(0.119$ per h, mean across seasons), although the difference with Pelvetia canaliculata was not significant $(P>0.05)$. The lag time was 0.00 for most of the seaweeds, with the exception of Pelvetia canaliculata, Palmaria palmata and Porphyra sp. (0.31, 1.19 and $0.05 \mathrm{~h}$, respectively). The DMED values ranged from 424 and $652 \mathrm{~g} / \mathrm{kg}$, and were higher $(P<0.05)$ for the three red seaweeds (Mastocarpus stellatus, Palmaria palmata and Porphyra sp.) than for the rest of seaweeds. Acrosiphonia sp. and Pelvetia canaliculata had the lowest $\left(P<0.05\right.$ ) TDMD $_{72}$ values, whereas Laminaria digitata and Palmaria palmata had the greatest values.

\subsection{In vitro rumen fermentation characteristics}

A period of $24 \mathrm{~h}$ of incubation was selected for assessing ruminal fermentation parameters, because it corresponds to a tumen passage rate of 0.041 per $\mathrm{h}$, which can be found in sheep consuming fibrous diets (Ranilla et al., 1998). There were differences among seaweed species in both total VFA production and profile (Table 3). Palmaria palmata had the highest $(P<0.05)$ VFA production, whereas Mastocarpus stellatus and Pelvetia canaliculata had the lowest values $(P<0.05)$. Seaweeds collected in autumn had lower VFA production compared with those collected in spring, and no seaweed species $\times$ season interaction $(P=0.213)$ was detected. The molar proportion of acetate was not affected eithet by the seaweed species $(P=0.408)$ or the season $(P=0.407)$. In contrast, molar proportion of the rest of VFA differed among seaweed species, with Palmaria palmata having the highest proportion of propionate and the lowest $(P<0.05)$ proportion of butyrate, these last values being similar $(P>0.05)$ to those for $P e l v e t i a$ canaliculata, Acrosiphonia sp. and Porphyra sp. There was a high variability in the acetate:propionate ratio, which ranged from 2.16 to 4.81, with Palmaria palmata showing the lowest value $(P<0.05)$ and Pelvetia canaliculata the highest $(P<0.05)$. Significant seaweed species $\times$ season interactions $(P<0.05)$ were observed for the molat proportions of acetate, propionate, butyrate and valerate, as well as for the acetate:propionate ratio.

Both seaweed species and season affected $(P<0.05)$ final $\mathrm{pH}$ values in the fermentation medium, ammonia- $\mathrm{N}$ concentrations and methane production (Table 4), but no seaweed species $\times$ season interactions were detected for these parameters $(\mathrm{P}=0.851$, 0.995 and 0.178 , respectively). Palmaria palmata had the lowest $(P<0.05) \mathrm{pH}$ values and the highest $(P<0.05)$ methane production. Higher $(P<0.05) \mathrm{pH}$ values and lower $(P<0.05)$ values of ammonia- $\mathrm{N}$ concentrations and methane production were observed for the samples collected in autumn compared with those collected in spring. In contrast, the ratio methane to total VFA was not affected $(P>0.05)$ by either the season ot seaweed species.

Table 4

Final $\mathrm{pH}, \mathrm{NH}_{3}-\mathrm{N}$ concentration. methane production. and methane/total volatile fatty acids (methane/ VFA) ratio after 24-h in vitro incubation in batch cultures of ruminal microorganisms different seaweed species collected during spring and autumn in northern Norway.

\begin{tabular}{|c|c|c|c|c|c|}
\hline Seaweed species & Season & $\mathrm{pH}$ & $\mathrm{NH}_{3}=\mathrm{N}(\mathrm{mg} / 100 \mathrm{ml})$ & Methane (mmol) & Methane/VFA $(\mathrm{mol} / \mathrm{mol})$ \\
\hline \multicolumn{6}{|l|}{ Brown seaweeds } \\
\hline \multirow[t]{3}{*}{ Alaria esculienta } & Spring & 6.70 & 32.6 & 0.596 & 0.181 \\
\hline & Autumn & 6.85 & 5.21 & 0.091 & 0.067 \\
\hline & Average & $6.78^{b}$ & $18.9^{\mathrm{a}}$ & $0.343^{4}$ & 0.119 \\
\hline \multirow[t]{3}{*}{ Laminaria digitata } & Spring & 6.79 & 42.1 & 0.467 & 0.148 \\
\hline & Autumn & 6.90 & 13.1 & 0.273 & 0.154 \\
\hline & Average & $6.85^{b}$ & $27.6^{\text {ab }}$ & $0.370^{\mathrm{gb}}$ & 0.151 \\
\hline \multirow[t]{3}{*}{ Pelvetia canalicitata } & Spring & 6.80 & 34.5 & 0.477 & 0.160 \\
\hline & Autumn & 7.00 & 4.13 & 0.139 & 0.190 \\
\hline & Average & $6.90^{t}$ & $19.3^{\mathrm{a}}$ & $0.308^{4}$ & 0.175 \\
\hline \multicolumn{6}{|l|}{ Red seaweeds } \\
\hline \multirow[t]{3}{*}{ Mastocarpus stellans } & Spring & 6.83 & 38.7 & 0.584 & 0.209 \\
\hline & Autumn & 7.02 & 19.6 & 0.11 & 0.128 \\
\hline & Average & $6.93^{c}$ & $29.2^{\text {ab }}$ & $0.348^{\mathrm{R}}$ & 0.168 \\
\hline \multirow[t]{3}{*}{ Palmaria paimata } & Spring & 6.49 & 41.4 & 0.981 & 0.195 \\
\hline & Autumn & 6.64 & 14.4 & 0.541 & 0.148 \\
\hline & Average & $6.57^{\mathrm{a}}$ & $27.9^{\mathrm{ab}}$ & $0.761^{t}$ & 0.172 \\
\hline \multirow[t]{3}{*}{ Porphyra sp. } & Spring & 6.83 & 59.6 & 0.567 & 0.175 \\
\hline & Autumn & 6.95 & 32.6 & 0.445 & 0.248 \\
\hline & Average & $6.89^{c}$ & $46.1^{c}$ & $0.491^{b}$ & 0.211 \\
\hline \multicolumn{6}{|l|}{ Green seaweeds } \\
\hline \multirow[t]{3}{*}{ Acrosiphonia sp. } & Spring & 6.83 & 55.2 & 0.556 & 0.153 \\
\hline & Autumn & 6.94 & 26.5 & 0.312 & 0.170 \\
\hline & Average & $6.89^{\mathrm{c}}$ & $40.9^{\mathrm{bc}}$ & $0.434^{b}$ & 0.162 \\
\hline \multicolumn{6}{|l|}{$P$ value } \\
\hline Species & & $<0,001$ & 0.011 & 0.002 & 0.873 \\
\hline Season & & $<0.001$ & $<0.001$ & $<0.001$ & 0.301 \\
\hline Species $x$ Season & & 0.851 & 0.995 & 0.178 & 0.587 \\
\hline SEM & & 0.012 & 2.31 & 0.0799 & 0.0471 \\
\hline
\end{tabular}

\footnotetext{
a.b: Within each column, average values for each seaweed not sharing the same superscript differ $(\mathbf{P}<0.05)$
} 


\subsection{Microbial abundance and diversity in cultures with red seaweeds}

The microbial concentrations and diversity of total bacteria, protozoa and methanogenic archaea in the cultures with Mastocarpus stellatus, Palmaria palmata and Porphyra sp. collected in spring as substrates is presented in Table 5 . There were no differences in the abundance of total bacteria, archaea and protozoa $(P=0.922,0.303$ and 0.367 , respectively) among the cultures with the three red seaweeds. The numbers of bands in the DGGE gels of individual samples ranged from 29 to 61 for bacteria, from 10 to 16 for archaea, and from 5 to 8 for protozoa. No differences $(P=0.230-0.444)$ among seaweeds were detected either in the number of bands or in the Shannon index.

Fig. 1 shows the dendrograms of the DGGE profiles of Mastocarpus stellatus, Palmaria palmata and Porphyra sp. samples after 24-h in vitro incubations in batch cultures. For all microbial populations analyzed, samples were separated by the incubation run and formed three clear clusters. The DGGE profiles of Mastocarpus stellatus and Porphyra sp. in the incubation runs 1 and 3 showed a similarity of $100 \%$ for archaea and greater than $96 \%$ for bacteria, but values in the incubation run 2 were lower $(95$ and $86 \%$ for archaea and bacteria, respectively). The three seaweeds showed a similarity of $100 \%$ for protozoa in the incubation runs 1 and 3 , but Palmaria palmata had a lower similarity (90\%) with Mastocarpus stellatus and Porphyra sp. in the incubation run 2 . No clear grouping of samples by seaweed species were observed for any of the microbial population analyzed.

\section{Discussion}

\subsection{Chemical composition, gas production kinetics and in vitro rumen fermentation characteristics}

The influence of seaweed species and collecting season on DM, ash, CP and aNDFom content has been discussed by Tayyab et al. (2016). Ether extract content was within the range reported in the literature for these seaweeds (Dawczynski et al., 2007; Makkar et al., 2016), with values below $30 \mathrm{~g} / \mathrm{kg}$ DM for all samples, which are lower than the value above that the growth of cellulolytic bacteria can be reduced $(50 \mathrm{~g} / \mathrm{kg}$ DM; Doreau and Chilliard, 1997). However, the negative relationship between EE content and both DMED $(r=0.628 ; P=0.016)$ and $\mathrm{DMD}_{72}(\mathrm{r}=0.742 ; P=0.002)$ may indicate a negative effect of fat on in vitro ruminal degradation of seaweeds. In fact, the seaweeds with the lowest fat content (Mastocarpus and Porphyra sp.) had the greatest DMED values (see Table 2), whereas those with greater EE content (Pelvetia and Acrosiphonia sp.) showed the lowest DMED values. This point deserves further investigation. In contrast, EE content was not related $(P>0.05)$ to either total VFA production or any of the gas production kinetics parameter (A, $c, \operatorname{lag}$ and AGPR). In general, brown seaweeds had greater NSC contents than red and green seaweeds in our study, which is consistent with the lower aNDFom observed in the brown seaweeds. Neither aNDFom nor NSC contents were related $(P<0.05)$ to $\mathrm{DMED}, \mathrm{DMD}_{72}$ or gas production kinetics parameters, which reflects the complexity of the compounds included in aNDFom and NSC fractions.

As previously reported by others (Belanche et al., 2016a; Makkar et al., 2016), there were marked differences among seaweeds in their TEP content. In general, the brown seaweeds had higher TEP contents than red and green seaweeds in our study, and those collected in spring had lower values than those sampled in autumn. Polyphenols in plants can protect proteins from degradation and improve the efficiency of use of nitrogen in ruminants by increasing the amount of by-pass protein, but can also reduce the rumen fibre degradation by decreasing the attachment of microbes to feed particles (Makkar, 2003). The negative relationships between the TEP content and the DMED $(r=0.544 ; \mathrm{P}=0.044)$ and $\mathrm{TDMD}_{72}(\mathrm{r}=0.602 ; \mathrm{P}=0.023)$ values, observed in the present study indicate a negative effect of TEP on in vitro rumen degradation of seaweeds. In contrast, no relationship $(P>0.05)$ was detected between the TEP content and any of the gas production kinetics parameters. As pointed out by Makkar (2003), gas measurements should be combined with determinations of microbial growth and/or feed degradability for a better interpretation of the effects of polyphenols.

There were important differences among seaweed species in their DMED, with Mastocarpus stellatus and Porphyra sp. showing the highest average values ( $>600 \mathrm{~g} / \mathrm{kg}$ ) and Acrosiphonia sp. and Pelvetia canaliculata the lowest (453 and $444 \mathrm{~g} / \mathrm{kg}$, respectively). Tayyab et al. (2016) using a in situ technique in dairy cows and the same seaweeds samples than those used in the present work found lower DM degradability values for Pelvetia canaliculata and Mastocarpus stellatus (246 and $270 \mathrm{~g} / \mathrm{kg}$, respectively) and higher for

Table 5

Microbial abundances and diversity (assessed as number of bands (NB) and Shannon-Weimer Index (SI) in DGGE gels) of total bacteria (16S rRNA), protozoa (18S rRNA) and methanogenic archaea (mcrA gene) in 24-h in vitro ruminal fermentations of different red seaweed species collected in northern Norway.

\begin{tabular}{|c|c|c|c|c|c|c|c|c|c|}
\hline \multirow[b]{3}{*}{ Red seaweeds } & \multicolumn{9}{|c|}{ Microbial diversity } \\
\hline & \multicolumn{3}{|c|}{ Microbial abundances, $\log _{10}$ (copies/g fresh matter) } & \multicolumn{2}{|c|}{ Bacteria } & \multicolumn{2}{|c|}{ Archaea } & \multicolumn{2}{|c|}{ Protozoa } \\
\hline & Bacteria & Archaea & Protozoa & NB & SI & NB & SI & NB & SI \\
\hline Mastocarpus stellatus & 7.48 & 4.92 & 8.04 & 34.0 & 3.51 & 13.7 & 2.60 & 6.67 & 1.88 \\
\hline Palmaria palmata & 7.86 & 6.17 & 9.51 & 41.0 & 3.66 & 13.7 & 2.60 & 7.00 & 1.94 \\
\hline Porphyra sp. & 7.96 & 6.61 & 8.89 & 37.0 & 3.58 & 13.3 & 2.57 & 6.67 & 1.87 \\
\hline$P$ value & 0.922 & 0.303 & 0.367 & 0.311 & 0.230 & 0.444 & 0.444 & 0.443 & 0.443 \\
\hline SEM & 0.760 & 0.596 & 0.561 & 2.42 & 0.044 & 0.17 & 0.161 & 0.167 & 0.031 \\
\hline
\end{tabular}



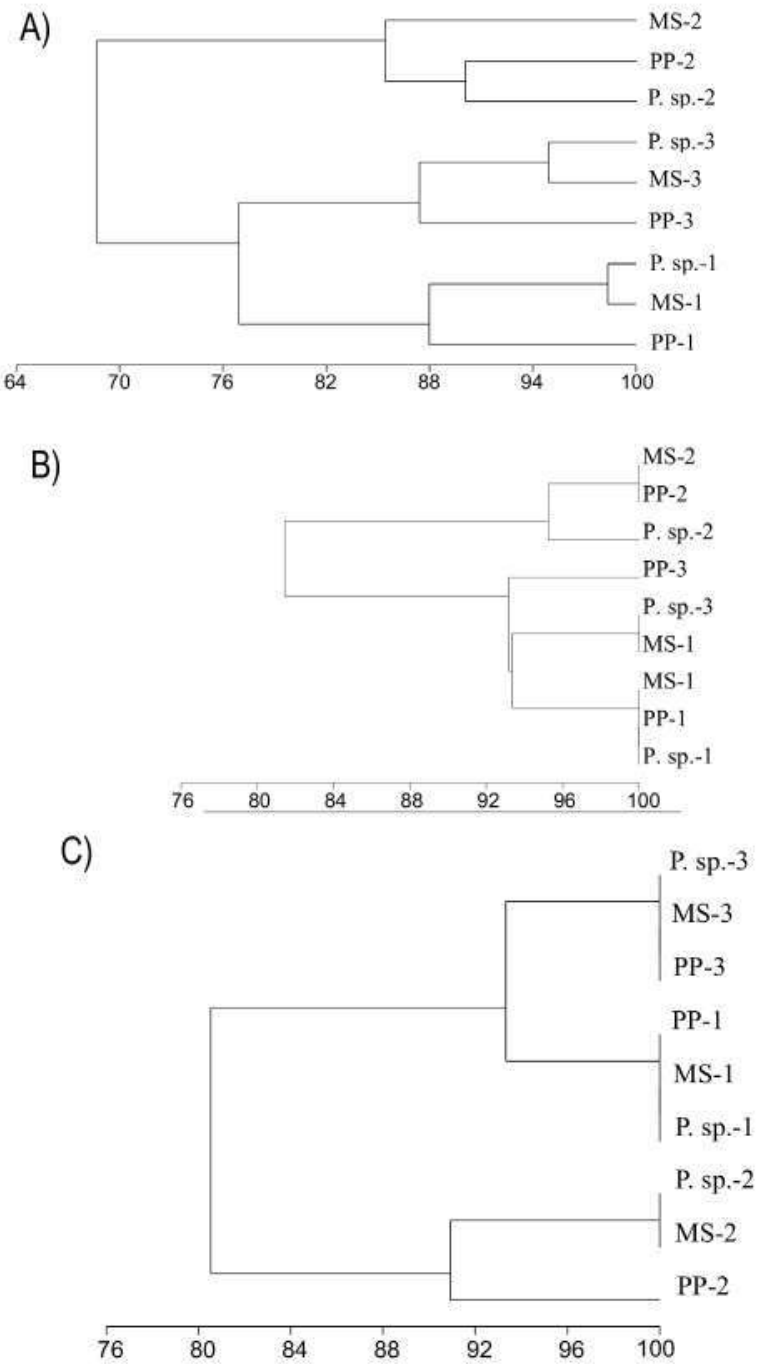

Fig. 1. Dendrograms of DGGE analysis of total bacteria (Fig. 1A), archaea (Fig. 1B) and protozoa (Fig. 1C) communities in 24-h in vitro ruminal fermentations of seaweeds from northern Norway. MS: Mastocarpus stellatus; PP: Palmaria palmata; P. sp.: Porplyra sp. Numbers 1-3 correspond to incubation runs. Scale bars show percentage of similarity.

Palmaria palmata ( $833 \mathrm{~g} / \mathrm{kg}$; values at $24 \mathrm{~h}$ incubation averaged across seasons) compared to the DMED values found in the present work. The differences in the results might be due to the use of different methodology (in vitro vs. in situ) and animal species (sheep vs. cows). However, the 24-h in situ degradability data determined by Tayyab et al. (2016) agree well with the VFA production measured after $24 \mathrm{~h}$ in vitro incubation in our study, with Palmaria palmata having the highest values (4.34 mmol of VFA and $833 \mathrm{~g} / \mathrm{kg}$ for in situ DM degradability) and Pelvetia canaliculata and Mastocarpus stellatus having the lowest values for both parameters (1.85 and $1.84 \mathrm{mmol}$ of VFA, respectively, and 245 and $270 \mathrm{~g} / \mathrm{kg}$ DM for in situ DM degradability). However none of the chemical constituents determined was correlated $(P>0.05)$ with total VFA production, with the exception of EE content and a trend to a negative correlation between the TEP content and the amount of total VFA produced $(r=0.470 ; P=0.090)$.

Seaweeds differed in their VFA profile, with Palmaria palmata having the highest propionate proportions ( 23.0 and $26.0 \mathrm{~mol} /$ $100 \mathrm{~mol}$ in spring and autumn, respectively) and the lowest acetate/propionate ratio (2.41 and 2.28). Conversely, Pelvetia canaliculata and Mastocarpus stellatus had the highest acetate/propionate ratios (4.29 and 4.48, and 3.85 and 4.17, respectively). High variations between seaweed species in the VFA profile in in vitro fermentations have also been reported by others (Kinley et al., 2016; Machado et al., 2016). Branched-chain VFA are generated from the degradation of some amino acids and their concentrations in in vitro cultures can be used as an index of protein degradation. Mastocarpus stellatus, Porphyra sp. and Acrosiphonia sp. had the highest molar proportions of isoacids $(6.63,6.61$ and $5.80 \mathrm{~mol} / 100 \mathrm{~mol}$, respectively; calculated as isobutyrate plus isovalerate), which is in agreement with the high ammonia- $\mathrm{N}$ values $(29.2,46.1$ and $40.9 \mathrm{mg} / 100 \mathrm{ml})$ observed in the cultures of these seaweeds and with the high CP content of these seaweeds (see Table 1), specially Porphyra sp. and Acrosiphonia sp. Alaria esculenta showed the lowest isoacids proportion and ammonia- $\mathrm{N}$ concentration $(3.56 \mathrm{~mol} / 100 \mathrm{~mol}$ and $18.9 \mathrm{mg} / 100 \mathrm{ml})$, despite its CP content was numerically greater than that of Laminaria and Pelvetia (see Table 1). Interpretation of isoacids proportions is difficult, as they are captured and 
used by the cellulolytic bacteria for their growth (Hume, 1970).

Several studies have investigated the effects of including seaweeds in the diet of ruminants on methane emissions, but results have been contradictory. Belanche et al. (2016b) observed no changes in methane production in Rusitec fermenters by including either one of the brown seaweed Laminaria digitata or Ascophyllum nodosum at $50 \mathrm{~g} / \mathrm{kg}$ in the diet (DM basis). In contrast, Kinley et al. (2016) and Machado et al. (2016) observed that the red seaweed Asparagopsis taxiformis was highly effective in decreasing methane production in batch cultures at doses as low as $20 \mathrm{~g} / \mathrm{kg}$ (organic matter basis), but higher doses also decreased VFA production. Machado et al. (2016) also reported an antimethanogenic effect of the freshwater green filamentous alga Oedogonium sp. at higher doses ( $>500 \mathrm{~g} / \mathrm{kg}$ organic matter). In our study, the positive relationship ( $\mathrm{r}=0.943 ; \mathrm{P}=<0.001$ ) observed between the amount of total VFA and methane production in the cultures indicates that methane production was directly related to the amount of substrate fermented, as both VFA and methane are produced in the fermentation of organic matter. This positive relationship might also indicate an absence of antimethanogenic compounds in any of the tested seaweeds, which is supported by the lack of differences between seaweeds in methane/total VFA ratio. Morever, the values of fermentation parameters $\left(\mathrm{VFA}, \mathrm{NH}_{3}-\mathrm{N}\right.$ and methane) were in the range of those obtained in previous studies by our group in batch cultures of sheep rumen microorganisms containing feeds commonly used in ruminants feeding (Martínez et al., 2010; Soto et al., 2015; Mateos et al., 2015, 2016), which would indicate that the tested seaweeds do not contain compounds inhibiting the growth of ruminal microorganisms. It should be noticed that in our study the diet fed to donor sheep did not contain seaweeds, and adaptation to seaweeds consumption might have changed the rumen microbial populations (Belanche et al., 2016b) and therefore the results obtained. In a recent review on the use of in vitro systems, Yáñez-Ruiz et al. (2016) indicated that the effects of differences in diet composition fed to donor animals may be minimized by obtaining rumen fluid immediately before feeding, and this approach was followed in the present study.

The differences between seasons, with spring-samples having higher DMED values and VFA production compared with autumnsamples, are in accordance with the results of Tayyab et al. (2016) for the same batch of seaweed samples. This would indicate that spring-collected seaweeds had higher nutritive value than those collected in autumn for both sheep and cows. These results are consistent with the lower CP content and higher aNDFom content for the autumn-seaweeds compared with the seaweeds collected in spring (see Table 1). Autumn-collected brown seaweed had higher TEP and are therefore of more interest when looking for bioactive effects from the seaweeds. However, a species $\times$ season interaction was detected in some of the parameters analyzed in our study, indicating differences in season effect among species. Moreover, other parameters such as the habitat and external conditions (water temperature and movement, sunlight intensity, nutrient concentration in water, etc.) might influence the chemical composition and nutritive value of seaweeds (Makkar et al., 2016).

\subsection{Microbial abundances and diversity}

The microbial analysis in the cultures could be conducted only in a limited number of samples due to economic and technical constraints. The three red seaweeds (Mastocarpus estellatus, Palmaria palmata and Porphyra sp.) collected in spring were selected for these analyses due to their relatively high CP content and high DMED values (Tables 1 and 2, respectively), and therefore their potential as feed ingredients in ruminant diets. These seaweeds differed markedly in their AGPR $(1.50-4.55 \mathrm{ml} / \mathrm{h})$, methane (0.567-981 mmol) and VFA production (2.79-5.02 mmol), as well as VFA profile (acetate:propionate ratios from 2.41 to 3.85). These variable fermentation patterns might indicate the existence of differences in the microbial populations promoted by these seaweeds. Contrary to our expectations, no significant differences in the abundance of any of the analysed microbial populations were detected. However, the abundance of bacteria in the cultures with Palmaria palmata was 20.6 and 10.8\% higher than that for Mastocarpus stellatus and Porphyra sp., respectively, which is consistent with the greater fermentability of Palmaria palmata, as indicated by its high VFA and methane production values (5.02 and $0.981 \mathrm{mmol}$, respectively).

The lack of differences between the three red seaweeds in the abundance of archaea contrasts with the variability observed in methane production in the same cultures $(0.584,0.981$ and $0.567 \mathrm{mmol}$ for Mastocarpus stellatus, Palmaria palmata and Porphyra sp., respectively). In agreement with other studies (Machmüller et al., 2003; Yáñez-Ruiz et al., 2008; Mateos et al., 2016), there were no relationship between the abundance of methanogenic archaea and the methane production $(\mathrm{r}=0.333 ; P=0.421$; $\mathrm{n}=9)$, indicating that there is no clear relationship between the number of methanogenic archaea and methanogenesis in the rumen.

The abundances of protozoa were similar to the values ranging from 8.24 to 8.66 (log gene copies/g fresh matter) reported by Soto et al. (2015) in an experiment with batch cultures containing four mixed diets (57:43 forage:concentrate) as substrates and conducted with the same in vitro and DGGE methodologies used in the present study. These results indicate that none of the tested red seaweeds had antiprotozoal compounds. In agreement with our results, Belanche et al. (2016b) also observed no effect of the $5 \%$ inclusion of two brown seaweeds (Laminaria digitata and Ascophyllum nodosum) in the diet on protozoa abundances in Rusitec fermenters, but Boeckaert et al. (2007) reported a decrease in the abundance of some protozoa in the rumen of dairy cows by feeding a unicellular fungi (Schizochytrium sp.; $2 \%$ of intake). It seems that different seaweed species can have variable effects on rumen microbial populations.

The number of DGGE-bands for bacteria (20-61) was similar to that previously reported in sheep and batch cultures (Belanche et al., 2012; Saro et al., 2014) using the same primers utilized in our study. The number of bands observed in the DGGE gels for protozoa (5-8) is consistent with the results of De la Fuente et al. (2009), who observed up to 8 bands in the rumen of goats using the same DGGE methodology utilized in our study. The lack of differences in the number of bands in the DGGE gels and in the values of Shannon index indicates a similar diversity of bacteria, archaea and protozoa in the cultures with Mastocarpus stellatus, Palmaria palmata and Porphyra sp. as substrates. The cluster pattern observed in the dendrograms of DGGE profiles indicates that the incubation run (inoculum) had the largest effect on all analysed microbial populations, as previously reported by others both in batch 
cultures (Mateos et al., 2015, 2016) and in the rumen of sheep (Saro et al., 2012, 2014). Although the rumen fluid used as inoculum was obtained from sheep that received the same standard diet during the in vitro experiments and rumen content was sampled immediately before feeding the three clear clusters formed according incubation run indicate differences in microbial populations among the rumen fluids used as inoculum in each incubation runs. Mateos et al. (2015) analyzed the changes in bacterial diversity over the in vitro incubation in batch cultures containing four different diets and inoculated with fluid from sheep fed the same diets, and observed that each batch culture sample showed the highest similarity index with its corresponding rumen inoculum. The results of the present study show the influence of the microbial populations in the inoculum on the microbial populations promoted by the seaweeds.

\section{Conclusions}

There were marked differences between the tested seaweed species in their rate and extent of rumen fermentation. The collection season significantly affected most of the analyzed parameters, and the seaweeds collected in spring had higher protein content and higher in vitro rumen degradability and lower total extractable polyphenols content compared with those collected in autumn. As indicated by the volatile fatty acid production, Palmaria palmata had the highest degradability in 24-h incubations, whereas Pelvetia canaliculata and Mastocarpus stellatus had the lowest. Further in vivo studies are required to identify the factors affecting the nutritive value of seaweeds for ruminants and to determine the optimal seaweed inclusion levels in the diets for ruminants.

The authors of the manuscript entitled "In vitro ruminal fermentation and methane production of different seaweed species" declare that there are no conflicts of interest.

\section{Acknowledgements}

Funding for this study was provided by the Research Council of Norway (Project Legumes and seaweed as alternative protein sources for sheep - AltPro- No 233682/E50, Norway). Thanks to J. Fernandez, L. Arbesú and I. Jimenez for technical assistance.

\section{References}

AOAC (Association of Official Analytical Chemists), 2005. Official Methods of Analysis, 18th ed. AOAC International, Gaithersburg, MD, USA.

Abecia, L., Rodríguez-Romero, N., Yañez-Ruiz, D.R., Fondevila, M., 2012. Biodiversity and fermentative activity of caecal microbial communities in wild and farm rabbits from Spain. Anaerobe 18, 344-349.

Abecia, L., Soto, E.C., Ramos-Morales, E., Molina-Alcaide, E., 2014. Microbial and chemical composition of liquid-associated bacteria in goats' rumen and fermenters. J. Anim. Physiol. Anim. Nutr. 98, 1001-1012.

Aguilera, J.F., Molina, E., Prieto, C., Boza, J., 1986. Determination of the energy requirements for maintenance in sheep of Segureña breed. Arch. Zootec. $35,89-96$.

Bay-Larsen, I., Vestrum, I.K.. Lind, V., Risvoll, C., Novoa-Garrido, M., Roleda, M.Y., 2016. Traditional to commercial use of seaweeds: cross-disciplinary perspectives in using local protein sources in Arctic sheep husbandry. Grassland Science in Europe 21: 693-695. In: Höglind, M., Bakken, A.K., Hovstad, K.A., Kallioniemi, E., Riley. H., Steinshamn, H. Østrem, L. (Eds.), The Multiple Roles of Grassland in the European Bioeconomy. Proceedings of the 26th General Meeting of the European Grassland Federation. 4-8 September. Trondheim, Norway. .

Belanche, A., de la Fuente, G., Pinloche, E., Newbold, C.J., Balcells, J., 2012. Effect of diet and absence of protozoa on the rumen microbial community and on the representativeness of bacterial fractions used in the determination of microbial protein synthesis. J. Anim. Sci. 90, 3924-3936.

Belanche, A., Ramos-Morales, E., Newbold, C.J., 2016a. In vitro screening of natural feed additives from crustaceans, diatoms, seaweeds and plant extracts to manipulate rumen fermentation. J. Sci. Food Agric. 96, 3069-3078.

Belanche, A., Jones, E., Parveen, I., Newbold, C.J., 2016b. A metagenomics approach to evaluate the impact of dietary supplementation with ascophyllum nodosum or laminaria digitata on rumen function in rusitec fermenters. Front. Microbiol. . http://dx.doi.org/10.3389/fmicb.2016.00299. 10 March, 2016.

Boeckaert, C., Fievez, V., Van Hecke, D., Verstraete, W., Boon, N., 2007. Changes in rumen biohydrogenation intermediates and ciliate protozoa diversity after algae supplementation to dairy cattle. Eur. J. Lipid Sci. Technol. 109, 767-777.

Cheng, Y.F., Mao, S.Y., Liu, J.X., Zhu, W.Y., 2009. Molecular diversity analysis of rumen methanogenic Archaea from goat in eastern China by DGGE methods using different primer pairs. Lett. Appl. Microbiol. 48, 585-592.

Dawczynski, C.. Schubert, R., Jahreis, G., 2007. Amino acids, fatty acids, and dietary fibre in edible seaweed products. Food Chem. $103,891-899$.

De la Fuente, G., Belanche, A., Abecia, L., Dehority, B.A., Fondevila, M., 2009. Rumen protozoal diversity in the Spanish Ibex (Capra pirenaica hispánica) as compared with domestic goats (Capra hircus). Eur. J. Protistol. 45, 112-120.

Denman, S.E., Tomkins, N.W., McSweeney, C.S., 2007. Quantification and diversity analysis of ruminal methanogenic populations in response to the antimethanogenic compound bromochloromethane. FEMS Microbiol, Ecol, 62, 313-322.

Doreau, M.. Chilliard, Y.. 1997. Digestion and metabolism of dietary fat in farm animals. Brti. J. Nutr. 78 (Suppl. (1)), S15-S35 S15.

Evans, F.D., Critchley, A.T, 2014. Seaweeds for animal production use. J. Appl. Phycol. 26, 891-899.

Goering, H.K., Van Soest, P.J., 1970. Forage fiber analyses: apparatus, reagents, procedures, and some applications. Agriculture Handbook. Agricultural Research Service, U.S. Dept of Agriculture, Washintong, DC, USA.

Holdt, S.L., Kraan, S., 2011. Bioactive compounds in seaweed; functional food applications and legislation. J. Appl. Phycol. 23, 543-597. http://dx.doi.org/10.1007/ s10811-010-9632-5.

Hook, S.E., Wright, A.G., McBride, B.W., 2010. Methanogens: methane producers of the rumen and mitigation strategies. Archaea. . http://dx.doi.org/10.1155/2010/ 945785. $11 \mathrm{p}$.

Hume, I.D., 1970. Synthesis of microbial protein in the rumen. II. A response to higher volatile fatty acids. Aust. J. Agric. Res, $21.297-304$.

Isac, M.D., García, M.A., Aguilera, J.F., Molina Alcaide, E., 1994. A comparative study of nutrient digestibility, kinetics of digestion and passage and rumen fermentation pattern in goats and sheep offered medium quality forages at the maintenance level of feeding. Arch. Anim. Nutr. 46 , $37-50$.

Julkunen-Tiito, R., 1985. Phenolics constituents in the leaves of northern willows: methods for the analysis of certain phenolics. J. Agric. Food Chem. 33, $213-217$.

Kinley, R.D., de Nys, R., Vucko, M.J., Machado, L., Tomkins, N.W., 2016. The red macroalgae Asparagopsis taxiformis is a potent natural antimethanogenic that reduces methane production during in vitro fermentation with rumen fluid. Anim. Prod. Sci. 56, $282-289$.

Machado, L., Magnusson, M., Paul, N.A., Kinley, R., de Nys, R., Tomkins, N., 2016. Dose-response effects of Asparagopsis taxiformis and Oedogonium sp. on in vitro fermentation and methane production. J. Appl. Phycol. 28, 1443-1452.

Machmüller, A., Soliva, C.R., Kreuzer, M., 2003. Effect of coconut oil and defaunation treatment on methanogenesis in sheep. Reprod. Nutr. Develop. 43, 41-55.

Maeda, H., Fujimoto, C., Haruki, Y., Maeda, T., Kokeguchi, S., Petelin, M., Arai, H., Tanimoto, I., Nishimura, F., Takashiba, S., 2003. Quantitative real-time PCR using TaqMan and SYBR Green for Actinobacillus actinomycetemcomitans, Porphyromonas gingivalis, Prevotella intermedia, tetQ gene and total bacteria. FEMS 
Immunol. Med. Microbiol. 39, 81-86.

Makkar, H.P.S., Tran, G., Heuzé, V., Giger-Reverdin, S., Lessire, M., Lebas, F., Ankers, P., 2016. Seaweeds for livestock diets: a review. Anim. Feed Sci. Technol. 212, $1-17$.

Makkar, H.P.S., 2003. Effects and fate of tannins in ruminant animals adaptation to tannins, and strategies to overcome detrimental effects of feeding tannin-rich diets. Small Rumin. Res, 49, 241-256.

Martinez, M.E., Ranilla, M.J., Tejido, M.L., Ramos, S., Carro, M.D., 2010. The effect of the diet fed to donor sheep on in vitro methane production and ruminal fermentation of diets of variable composition. Anim. Feed Sci. Technol. 158, 126-135.

Martínez-Fernández, G.. Abecia. L., Martín-García, A.I., Ramos-Morales, E., Denman. S.E., Newbold, C.J., Molina-Alcaide, E., Yañez-Ruiz, D.R., 2015. Response of the rumen archaeal and bacterial populations to anti-methanogenic organosulphur compounds in continuous culture fermenters. FEMS Microbiol. Ecol. 91 fiv079.

Mateos, I., Ranilla, M.J., Saro, C., Carro, M.D., 2015. Comparison of fermentation characteristics and bacterial diversity in the rumen of sheep and batch cultures of rumen microorganisms. J. Agric. Sci. 153, 1097-1106.

Mateos, I., Ranilla, M.J., Saro, C.. Ramos, M., Carro, M.D., 2016. Influence of processing method of rumen contents on microbial populations in the inoculum and in vitro fermentation of substrates of variable composition. Anim. Feed Sci. Technol. 220, 109-120.

Mertens, D.R., 2002. Gravimetric determination of amylase-treated neutral detergent fiber in feeds with refluxing in beakers or crucibles: collaborativestudy. J. AOAC Int. $85,1217-1240$.

Muyzer, G., de Waal, E.C., Uitterlinden, A.G., 1993. Profiling of complex microbial populations by denaturing gradient gel electrophoresis analysis of polymerase chain reaction-amplified genes coding for 16S rRNA. Appl. Environ. Microbiol. 59, 695-700.

Odegard, I.Y.R., van der Voet, E., 2014. The future of food-Scenarios and the effect on natural resource use in agriculture in 2050. Ecol. Econ. 97, 51-59.

Ranilla, M.J., Lopez, S., Giráldez, F.J., Valdés, C., Carro, M.D., 1998. Comparative digestibility and digesta flow kinetics in two breeds of sheep. Anim. Sci. 66, $389-396$.

Regensbogenova, M., Pristas, P., Javorsky, P., Moon-van-der Staay, S.Y., van der Staay, G.W.M., Hackstein, J.H.P., Newbold, C.J., McEwan, N.R., 2004. Assessment of ciliates in the sheep rumen by DGGE. Lett. Appl, Microbiol. 49, 144-147.

SAS, 2012. SAS User's Guide, 9.1.2 edn. SAS Institute Inc. Cary, NC, USA.

Saro, C., Ranilla, M.J., Carro, M.D., 2012. Postprandial evolution of the microbial community in the rumen of sheep fed diets varying in type of forage as assessed by real-time PCR and ARISA. J. Anim. Sci. 90, 4487-4494.

Saro, G., Ranilla, M.J., Cifuentes, A., Roselló-Mora, R., Carro, M.D., 2014. Technical note: comparison of automated ribosomal intergenic spacer analysis (ARISA) and denaturing gradient gel electrophoresis (DGGE) to assess bacterial diversity in the rumen of sheep. J. Anim. Sci. 92, 1083-1088.

Soto, E.C., Khelil, H., Yánez-Rúiz, D.R., Carro, M.D., Molina-Alcaide, E., 2015. Use of tomato and cucumber horticulture by-products in goat diets: effects on rumen fermentation and microbial communities in batch and continuous cultures. J. Agric. Sci. 153, 343-352.

Steinfeld, H., Wassenaar, T., 2007. The role of livestock production in carbon and nitrogen cycles. Annu. Rev. Environ. Resour. 32, 271-294.

Sylvester, J.T., Karnati, S.K., Yu, Z., Morrison, M., Firkins, J.L., 2004. Development of an assay to quantify rumen ciliate protozoal biomass in cows using real-time PCR. J. Nutr. 134, 3378-3384.

Tayyab, U., Novoa-Garrido, M., Roleda, M.Y., Lind, V., Weisbjerg, M.R., 2016. Ruminal and intestinal protein degradability of various seaweed species measured in situ in dairy cows. Anim. Feed Sci. Technol. 2013, $44-54$.

Van Soest, P.J., Win, R., Moor, L., 1966. Estimation of the true digestibility of forages by the in vitro digestion of cell walls. In: Proceedings of the 10th International Grassland Congress. Helsinki (Finland). pp. 438-441 (10).

Weatherburn, M.W.. 1967. Phenol-hypochlorite reaction for determination of ammonia. Anal. Chem. 39, 971-974.

Yánez-Ruiz, D.R., Hart, K.J., Martin-Garcia, A.I., Ramos, S., Newbold, C.J., 2008, Diet composition at weaning affects the rumen microbial population and methane emissions by lambs. Aust. J. Exp. Agric. 48, 186-188.

Yanez-Ruiz, D.R., Bannink, A., Dijkstra, J., Kebreab, E., Morgavi, D.P., O’Kiely, P., Reynolds, C.K., Schwarm, A., Shingfield, K.J., Yu. Z., Hristov, A.N., 2016. Design. implementation and interpretation of in vitro batch culture experiments to assess enteric methane mitigation in ruminants-a review. Anim. Feed Sci, Technol. $216,1-18$.

Yu, Z., Morrison, M., 2004. Improved extraction of PCR-quality community DNA from digesta and fecal samples. Biotechniques 36, 808-812. 